\title{
Kuwaiti Women Writers and Anglophone Choices: Charting New Territories
}

https://doi.org/10.33806/ijaes2000.22.1.17

\author{
Shahd Alshammari \\ Gulf University for Science and Technology, Kuwait
}

Received on 29.5.2021 Accepted on 1.11.2021 Published on 1.1.2022

\begin{abstract}
While there has been a plethora of work on Arab women writers, little attention has been paid to Kuwaiti women writers, especially those who write Anglophone literature. This research paper argues that the choice to write in English rather than Arabic leaves these writers in a problematic position. As a result of embracing the English language, rather than their mother tongue, they are left outside of the dominant literary circle and often marginalized. Through a literary analysis, this paper presents some of the texts written by contemporary Kuwaiti writers who have chosen to write in English, and have produced nuanced narratives of Kuwaiti women who find agency and self-expression through their fictional journeys. These journeys explore themes of agency, voice, and trauma. A significant contribution of the present paper lies in a thematic analysis of lesser-known Kuwaiti texts in order to excavate these marginalized voices. The findings suggest that by choosing to write in English, these writers face the dangers of being dismissed from the literary canon, just like their protagonists must contend with society's discrimination and expectations.
\end{abstract}

Keywords: Anglophone, Kuwait, Kuwaiti fiction, Middle East, women

\section{Introduction}

Arabic literature includes categories like Anglophone literature, Arab-American literature, and others. Other lesser-known categories include Gulf literature and even more specifically, Kuwaiti literature. While Kuwait boasts popular literary names such as Ismail Fahad Ismail, Layla Al-Uthman, Saud Alsanousi, Fawzia AlShuwayash, there remains a largely neglected group of writers who write in English. This is a marginalized group and remains outside of the dominant literary scene. The literary culture in Kuwait centers around writers who write in Arabic. The cultural and literary support takes it for granted that as Kuwaitis, the writers will choose to write in their mother tongue. Arabic is seen as a prerequisite to becoming part of the literary circle. For example, the country's major literary group is "Rabitat Al-Udaba's" (The Writers' Association) established in 1964 and to be part of the group one has to be a published Kuwaiti writer writing in Arabic (AlRabeta Website). It is rather exclusionary and aims to accentuate a national identity that relies on Arabic as the language of all artistic expression. Rabitat Al$U d a b a$, amongst other organizations, aims to promote the proliferation of Kuwaiti literature (literature by Kuwaitis written in Arabic). Short story competitions, publications of novels, short story collections, scholarly work, and other literary 
endeavors remain part of the country's agenda to produce, promote, and preserve a national (Kuwaiti) identity (Tijani, 2019).

Literature scholars have examined Kuwaiti women's writing in Arabic (Bernard and Rabadi, 2020; Tijani, 2008; 2016; 2019; 2020). Kuwaiti literature written by Kuwaiti authors who adopt the English language as the medium of literary expression is a neglected and under-researched subgenre of Kuwaiti literature. As Tijani (2019: 11) correctly notes:

The growth of the novel in Kuwait was very slow in the period before the 1990s. Evidently, the Iraqi invasion and occupation gave rise to a rapid development of this genre among Kuwaitis, as they have searched for more narrative space than what the short story allows to document the experience. With this development, the Kuwaiti novel has displayed a greater variety of innovative techniques and approaches to depicting its subjects than in previous decades. Yet while there are many scholarly works on other genres of modern Kuwaiti literature, such as poetry, the short story, and drama, it is difficult to find scholarly monographs in Arabic or English on the Kuwaiti novel, either detailing the history of its development or dedicated exclusively to its form and content.

Tijani's work (2019) focuses primarily on the Kuwaiti novel written in Arabic. He aims to historicize the emergence of the Kuwaiti literary scene throughout the twentieth century and chart its growth and changes to contemporary writers. He offers a comprehensive literary study of the diverse genres that have been produced by short story writers, poets, dramatists, and novelists. Tijani does not mention Kuwaiti writers who write in English. There is no footnote devoted to them in the margins. They remain in the margins and the genre remains a subgenre of Kuwaiti literature. For the purpose of this paper's discussion, I will identify a couple of Kuwaiti women authors who write in English and attempt to negotiate and contest their literary work within the category of "Kuwaiti literature." Due to the scarcity of critical readings of Kuwaiti women's literature, I present examples from their work to show their choice of subject matter and themes. These works include Mai Al-Nakib's The Hidden Light of Objects and Layla Al-Ammar's The Pact We Made (2019). Only these two novels will be analyzed in-depth in this paper because they are full-length novels with similar themes of female agency. There are also a couple of Kuwaiti poets and novelists writing in English such as Nada Faris (Mischief Diary, 2017) Shahd Alshammari (Notes on the Flesh, 2017) and Nejoud Al-Yagout (When the Haboob Sings, 2019). Alshammari's Notes on the Flesh deals with disability in Kuwait, a theme that is rarely explored in Kuwaiti literature. Faris's Mischief Diary is a coming-of-age narrative of a young Kuwait girl and is classified as Young Adult Literature, a genre that is also rare in Kuwaiti literature. Al-Yagout's poetry and novel When the Haboob Sings deals with mental health issues, a topic still stigmatized in Kuwait. All of the authors mentioned are women, which is a significant part of their literary expression and their subsequent marginalization in the literary scene. 
In Hanadi Alsaman's detailed study of Arab women's authorship (2015), she uses two literary motifs to examine the position of Arab women writers: Shahrazad and the buried infant child (The maw'udah) in the Pre-Islamic era. There is an "urgency of locating Shahrazad's literary trace in the traumatic past of the maw'udah tradition to resurrect women's body and word to ensure feminine agency in reconstructing cultural and national narratives." (13) Alsaman's work focuses on Arab women writers writing in Arabic. Throughout this paper's presentation of Kuwaiti texts, I wish to expand that focus to include Arab women writers writing in English, specifically Kuwaiti women writers who are at risk of being buried within the larger national literature. The threat of the ma'wudah tradition hovers in the background and I intend to amplify these contemporary literary voices to widen the definition of Kuwaiti literature and focus on the writers' agency in their thematic and narrative choices. In her article on "The Creative Arab Woman," Fawzia AbuKhaled (2014) argues that women writers are capable of influencing and creating new images of Arab women, going against the stereotypical images that are deeply embedded in the collective memory. Abu-Khaled suggests that there are more stereotypical images than alternative images to be found in the literary discourse. This is partly the rest of the "marginalization of women's attempts to produce any other image, and the act of preventing them from creating their own... keeping them away from the domain of knowledge production, which is why this image is colored with absence and alienation" (109). Abu-Khaled traces different images of women in fiction to arrive at the conclusion that there needs to be more multifaceted images of Arab women in the texts produced by women writers. The fiction presented in this paper deals with Kuwaiti women's social issues and deep psychological states of being. The texts are chosen primarily based on the criteria of language and themes: being written in English and dealing specifically with women's bodies, identities, and trauma. As such, these texts showcase multifaceted images of Kuwaiti women and their fictional journeys.

\section{Kuwaiti Literature: Between Past and Present}

Literary historians such as Tijani chart the short story and the novel as the beginning of a Kuwaiti literary scene and focus on the usage of the Arabic language and narrative techniques. There is an erasure of Kuwaiti women writers writing in English. Abdo (2009) contends that:

The tradition of short story writing in Kuwait is by Arab women writers writing in Arabic. Al-Shammari writes in English. In that regard, she can be seen in the company of another young and emerging Anglophone Kuwaiti woman writer, Layla al-Ammar... Similarly straddling two cultures, both authors focus on the tensions that their protagonists must navigate when caught between the contradictory worlds of modern Kuwait (59).

Abdo's suggestion that authors writing in English are navigating two cultures is not far off. Kuwaiti women writers write from beyond the constraints of language and tradition. They break free from the literary traditions of Kuwaiti literature to 
give birth to contemporary explorations of literary narration, voice, and themes. Kuwaiti literature in English falls into the category of what Steven Kellman calls translingualism; that is, it is authored by writers who have consciously chosen to write in a language other than their native one. As Kellman (2000) notes, by "refusing to be constrained by the structures of any single language, translinguals seem to acknowledge and to defy the claims of linguistic determinism" (24). Kuwaiti writers writing in English are defying linguistic traditions and expectations. To be embraced as a Kuwaiti author, one needs to highlight an intimacy with the Arabic language, the mother tongue, and show this relationship as the most significant one in the writing process. Narrative and literary techniques are secondary to the language used to produce the text. Although writing in one's mother tongue is not a prerequisite to literary production, there is an uneasiness about accepting Kuwaiti literature written in English. Mahmoud (2018) poses questions about what constitutes Kuwaiti literature and laments the rejection of "minor" Kuwaiti literature (written in English). He classifies it as minor literature because it is marginalized and excluded from "the major" Kuwaiti literary scene. Literary merit comes into question because of the choice of language used to narrate: "Kuwaiti authors who choose to write in English are condemned with a somehow collective(ethical) verdict that the literary merit of their literary products will always be questioned and most probably downgraded" (Mahmoud, p. 113). The question of national heritage and Arabness is part of the controversial conversation. Mahmoud draws on multiple examples amongst them is the individualized attacks narrated by authors who must defend their choice to write in English. Kuwaiti women writers must continuously justify the choice to write in English as if that choice begets a betrayal of the mother tongue. Mahmoud offers an example that takes place at the annual Kuwaiti Book Fair, where one of the authors gets attacked for writing in English. A "nameless man" asks the author if she is even Arab and wants to know why she would write in English if has Arab "blood" in her veins (113). It is an intriguing incident for Mahmoud to mention but it is much more concerning than a passing remark. The author's identity is threatened and called into question. How can one dare to speak in a language that they cannot call the mother? How can they choose to write in English and call it an intimate language, if it is not the mother tongue? It is the stepmother, the affair, the language of the other. This division of English/Arab is not only exclusionary but borders on a sort of adultery that the woman writer has committed. In his article "Promiscuous Tongues" Kellman (2013) asserts: Writers who switch tongueseither by translating a text into a different language or by composing original work in a language other than their primary one - are the libertines of the literary world (36).

Given the conservative nature of Kuwaiti society, being a libertine (especially for women) is a promiscuous act. The act of writing in English becomes a dangerous act. It is not simply a choice, but rather it becomes a symbolic act of protest. Women writers are expected to write within the patriarchal discourse if they are to be welcomed into the dominant literary culture. Hassan (2017), the editor of the Oxford 
Handbook of Arab Novelistic Traditions, points out in the introduction of the book, that Gulf literature remains to be an "understudied" field (7). Gulf literature in English is even more neglected and there is hardly any scholarship on the texts that are produced by women writers choosing to write in English. The choice of writing in English places these women writers outside the margins of the dominant literary culture. As such, these writers are writing against the patriarchal discourse of "Kuwaiti literature." Not only is Gulf literature neglected, but Kuwaiti women writers are doubly marginalized. They must carve out a place within the larger male-dominated literary realm and still create a "literature of their own" to quote Elaine Showalter's seminal work (1999). Kuwaiti women writers who write in Arabic are received more favorably than their counterparts who choose to write in English. There is very little scholarship about their work and perhaps the only names that continue to be mentioned in critical studies are Laila Al-Uthman, Fawzia Al-Shuwaysh, Hidaya Al-Salim (Tijani, 2017). These writers, as mentioned earlier, write only in Arabic. Although their work is noteworthy and demands further scholarship, they still face the issue of censorship, having published in Kuwait and in Arabic. In his chapter on Kuwaiti literary history, Tijani (2017) concludes that:

Kuwaiti women writers are worst hit by censorship: a good number of their publications are banned in the country because those texts venture into the depiction of sexualized topics considered taboo in Kuwaiti society. Partly to avoid censorship, some Kuwaiti writers have their works published outside the country, often in Syria, Lebanon, and Egypt (282).

As such, given the social and political circumstances of dealing with difficult topics of the female body, identity, and trauma, perhaps an affair with English is not too far-fetched. It offers a different medium - English - one that is intimate and offers a way to decode the intricacies of the body. Barthes (1978) describes language as an intimate body part, "le langage est une peau" [language is a skin]. If language is another skin, an extension of the body, then women writers who write in English can adapt to their environment by changing skin color (and skin pattern) in a chameleon-like way. This process is one way that they are creating a literary subculture. Nada Faris, a Kuwaiti writer and poet, coins the term "Anglowaiti" to refer to Kuwaiti writing in English. Anglowaiti literature is Faris's offered term that allows room for embracing the Anglophone in Kuwaiti literature, the two seemingly opposing identities. While this is one way to categorize Kuwaiti literature written in English, there is the question of adopting another language to write and why doing so results in a sort of exile from the Kuwaiti literary culture (Faris, 2013:21). Anglowaiti literary subculture is subversive and daring, allowing room for language to be freed from any constraints and taps into the semiotic chora that Julia Kristeva discusses in her seminal work Revolution in Poetic Language (1984). Kristeva (1984) sees the text as a place of disruption of language, of the symbolic order, and a place to break free from traditional linguistic structures. In the same vein, Kuwaiti women writing in English are taking part in a literary subculture, a revolution that 
revolution pushes against the homogenous "Arab" text and breaks free from the tradition of "Kuwaiti" literature to encompass hybrid literary texts.

Kuwaiti texts written in English fall under a hybrid category that is first seen in the choice of English as the medium of expression and later in the actual narratives. The narratives are subversive in their protagonists' refusal to remain in a stereotypical image of Kuwaiti women. In his article on Kuwaiti literature, Mahmoud concludes that "Kuwaiti literature in English, I dare say, is rhizomatic par excellence." (Mahmoud, 2018:117). This description is not random and he sees the writing as rhizomatic in its ability to create multiple sites of tension and grow from within these cites to create minor revolutions, although these revolutions are not "political in the Deleuzian sense." (Mahmoud, 2018:117). But it is a minor revolution as an act of speaking; to speak about the stigmatized body is an act of protest, a writing that is a form of agency. Contemporary Kuwaiti literature in English written by Kuwait women is still young; it is still rhizomatic and the possibilities are endless. Julia Kristeva, in an interview with Alison Rice, "Forgiveness: An Interview" states that writing in a foreign language provides some distance from trauma and offers new possibilities of expression. She contends: "Writing, speaking, another language is a relatively new experience; we have only been doing it for several centuries. And it is at once a great difficulty, a sort of tragedy, and a choice, an opportunity. We do not yet know the possibilities that this can open up" (Kristeva, 2002: 287). Kuwaiti literature in English is very young, and it is also a "new experience" for writers, readers, and literary critics. In adopting English to write about Kuwaiti female protagonists, these writers are actively subverting the status quo of Arabic literature. The texts are rhizomatic in their growth and their position and, as Kristeva (2002) asserts, we do not know where this will take us. Contemporary Kuwaiti women writers will continue to produce novels, short stories, poetry, and this will help create a new subgenre and subliterary culture, charting new literary terrain. The texts outlined below are a selection to allow us room to explore how these Kuwaiti women writers are tapping into the third space in their bilingualism.

\subsection{The Hidden Light of Objects: Mothers, Daughters, and Trauma}

Mai Al-Nakib is the author of the collection of short stories The Hidden Light of Objects (Al-Nakib, 2014). Al-Nakib is an Associate Professor of English Literature and continues to teach at Kuwait University. As an academic, her training is in literary criticism and Comparative literature. Influenced by Western literature and critics, Al-Nakib writes in English and studies Middle Eastern culture in both her creative and academic work. Al-Nakib has a problem with generalizing Arabic literature and urges readers to consider it beyond the homogenizing category of Arab. In her article on "Arab Literature: Politics and Nothing But", she argues that: "It becomes detrimental when all Arab literature is assumed to be political and not much more than that. It becomes a categorization that prevents readers from seeing what else might be going on in addition to politics" (Al-Nakib, 2014:4). Al-Nakib diagnoses the condition of Arab literature whether it is written in English or in 
Arabic as a difficult one: readers continue to anticipate that Arab writers will depict the nation's political turbulences. Other themes are not granted much attention, including trauma, voices of women, disability, individual politics, love, etc.

Al-Nakib's work (both academically and creatively) calls for deconstructing stereotypical images of Arab women. The multiplicity of themes in Al-Nakib's work deserves more critical attention as she interrogates time, nostalgia, memory, transgression, the traumatized body, and other multilayered notions of identity. AlNakib's The Hidden Light of Objects is not a collection that aims to capture Kuwaiti society for the reader. The stories are structured ambiguously and divided by vignettes that are lyrical and magical in their description of ordinary moments. In one of the passages in vignette three, Al-Nakib (2014) writes: "Encounters are contingent. The unique beauty of a perfect encounter is in its chance occurrence...the very best encounters are over in a flash, leaving behind a residue of sparks glinting in the afternoon sun (167). Al-Nakib's collection of stories are all short but offer a multilayered framework to examine Kuwaiti literature. Each story is an encounter with a character that faces the complexities of life in a patriarchal society. Others are caught between the past and present, between Kuwait pre-oil and post-oil, and protagonists carve out their own sense of self amidst the chaos of family obligations, cultural expectations, and fragments of memory.

Some of the characters are transgressors, such as in the case of Mama Hayat in "Echo Twins." Mama Hayat is a character that stands out in her inability to fit into a stereotypical image of a woman or a mother. Hayat, like her name, is filled with life even when life is cruel to her. Hayat's story is one of a transgressive woman in a conservative society. She refuses to follow patriarchal norms and continues to live on the margins of society, choosing to remain unmarried until she falls in love with a white man, Alexander. In a conservative culture, in this case, Kuwaiti society, this is the ultimate transgression: her choice to marry outside of Kuwait's national and social boundaries. Hayat's marriage with Alexander is a transgression that is later corrected by the men in the neighborhood with a brutal murder of Alexander. Hayat's life is one that offers a non-stereotypical image of Kuwaiti women in fiction. Al-Nakib creates a memorable protagonist who authors her own life and fights against Kuwaiti society's expectations and oppression of women.

The final story in Al-Nakib's collection is "The Hidden Light of Objects" (the main title is named after it), and it is this story that demands the most critical attention. It is a narrative of a woman who returns to her homeland after the Gulf War and must reacquaint herself with her surroundings, daughters, husband, and life outside of imprisonment. Zaina has been held captive, a prisoner of war, for ten years. Her daughters are unable to ask the most pressing questions that they need to ask "Had she been starved? Tortured? Had what normally happens to women's bodies in war happened to her? Would she be the mother who kissed our BandAids? (Al-Nakib, p. 218). There is a silence that cannot be broken by those most bound to her, the intimacy of family and what family takes for granted is shattered. 
There is no normalcy and nothing is the same with the return of Zaina. Her silence is a clear symptom of trauma:

During her second week...my mother sleeps the sleep of the dead. We can't wake her... She doesn't shower. She doesn't speak a word...We are scared, unsure what to do...Where are the experts?...Will she ever want to speak again? Ghusoon mentions trauma and elective mutism.

We can not picture our mother silent forever." (223)

Zaina's return to Kuwait does not mean she has actually returned to her family or herself. The rape of the nation during the Iraqi invasion of Kuwait in 1990 and the war's aftermaths haunt the text and the symbols are inscribed onto Zaina's body and the objects around her, her only ability to reconnect to her home. AlNakib's discussion of the Iraqi invasion is subversive in its vagueness, its philosophical meditation of time, home, the familiar and unfamiliar. It is not a documentation of war through a political lens. It is not a social critique. It is a personal, reflective and meditative testimony to the way that women experience trauma, memory, and belonging. In this sense, the personal is political, but with a more multifaceted meaning that unsettles our understanding of "personal" and "political." Zaina does not recognize herself or her body and yet is able to connect to "a litany of objects" that reminds her of her dispossessed body and her life before she was abducted (227). These objects are "more familiar" to her than her body. Shaking our understanding of the maternal and of home, Al-Nakib offers us Zaina's journey back home, like a modern-day Odysseus. Zaina's return home is uncanny and unexpected and her journey back is both real and mythological in its complexities. Family connections and her connection to public and private space, her daughters, and her understanding of home are all called into question as she attempts to return to the motherland, physically and psychically. Motherhood and its implications and expectations are part of Zaina's identity as a mother but she also struggles to locate herself within the home and within her own body.

Al-Nakib's collection of stories does not capture one image of Kuwaiti culture, Kuwaiti women, nor does it weave a simplistic narrative of the nation. Kuwait is presented as pre-oil Kuwait, post-oil, and post-Gulf war. The Hidden Light of Objects won the Edinburgh International Book Festival's First Book Award in 2014, the first short story collection to win in the history of the award. Despite its richness, it has not been granted enough critical attention, nor has it been hailed as part of the Kuwaiti literary canon. Al-Nakib is not part of the literary culture in Kuwait and her work is not found in bookstores in Kuwait. Because she writes in English her work is still placed outside the dominant literary circle.

\subsection{The Pact We Made: Identity and Trauma}

The novelist and academic Layla Alammar released her debut novel The Pact We Made in 2019 and, like Al-Nakib, writes both creatively and academically. Her scholarly work centers on Arab literature and trauma and her novel explores the intricacies of trauma and the body in positioning Dahlia, the protagonist, as a Kuwaiti woman who will not fit into any stereotype. The book has been hailed as 
another \#Metoo narrative (it even says so on the back cover of the book). Alammar's work (2019) is beginning to receive critical attention. As a halfAmerican/half-Kuwaiti hybrid, her work centers on images of women's agency, voice, and individuality. Like Al-Nakib, Alammar's prose is lyrical and beautifully crafted. Long and elaborate passages accentuate her command of the English language, and yet, she uses Kuwaiti words in her text and does not provide translations or footnotes. This conscious choice places her text in an ambiguous position. The text assumes its audience is English-speaking and with some knowledge of the Arabic language and Kuwaiti culture with its specific phrases ("dara'a, yumma, hayati"). This linguistic strategy might seem to alienate to a Western reader, but it also places the text as yet another rhizome, allowing room for linguistic and cultural potential, for multiplicity, and ambiguity. Abdo (2019) writes extensively on the usage of linguistic choices in Anglophone texts written by Arab authors and suggests that when Arabic phrases are not translated and "appear within passages of beautifully constructed English" this creates a hybrid text (2019). This hybridity creates a new third space, a space that alienates "English -speaking readers from their own language and estranging Arabic from the Arabicspeaking readership". Alammar's text (2019) is courageously subversive in its linguistic and narrative choices. The text, like its protagonist, thirty-year-old Dahlia, makes its own bold choices that are jarring and unsettling to the reader. Dahlia must choose between her traditional life, conservative family and her freedom. To find herself and feel a sense of freedom, she must leave Kuwait and start her journey into the unknown. Dahlia's issues stem from a deep personal history with her body and her stigmatization within Kuwaiti society. Dahlia is sexually traumatized and carries the shame and stigma within her body. As the narrative unfolds, we discover that Dahlia is silenced because of the patriarchal society's oppression of women's bodies and the guilting of women who are raped. "Therapy was a no-no; divulge our shame to a stranger? One who might know friends and family? ... It's not difficult to act like a normal person...I've been doing it for fifteen years" (Alammar, 2019:28). Dahlia's trauma is inextricably bound with shame and silence throughout the narrative. Mental health in Kuwait, like disability, is a taboo subject and remains one that leaves many people silenced as they navigate mental illness and the medical system. Because of Kuwait's collectivist society, there is a resistance to getting help from a psychiatrist or therapist who may know someone connected to the family (Alenaizi, 2018). The reputation of the family is mostly at stake and people carry that burden throughout their lives, in the same way that Dahlia does. In their short study on the state of mental health in Kuwait, psychiatrists Al-Mazeedi and Alsuwaidan (2014) offer an extensive analysis of the society's stigmatization of people living with mental illness:

Although there are no studies showing the extent of this mental illness stigma in Kuwait, research done in Arab communities reveals that it may exist at an even higher level than in Western developed countries... There is also a tendency for Arab families who care for a family member with a 
mental illness to experience fear, embarrassment, and disgrace of family reputations leading to feelings of secrecy and isolation. Both public and self-stigma may negatively affect patients' quality of life and influence treatment outcomes (2).

Dahlia's journey through her trauma and healing is delayed because of stigma and silence. She retreats deep into her own self, unable to communicate freely, and descends into an inner world where she is constantly haunted by nightmares and monsters that she sketches. Her only self-expression is through her art, as she continues to explore her fears and emotional state through dark sketches of monsters who visit her at night. Like Al-Nakib's protagonist, Zeina, Dahlia must perform an act for her family and bury her traumas. Even when she speaks, her voice is muffled, she hesitates, she stutters and stammers. Both Zeina and Dahlia are unable to speak of their trauma in front of their families. Both of these protagonists are struggling against patriarchal oppression that renders them invisible and would rather have them dead, revisiting the maw'udah trope in literature. Alammar's treatment of mental illness in her narrative is significant and reflects Kuwaiti society's unease with mental illness. In one of her short pieces, author Alammar reflects on literature, trauma, and voice:

Literature is a reflection, more often than not a dark reflection, of the world we live in and all the horrors we're capable of inflicting on one another. It seeks to represent what cannot be represented, to give shape to formless chaos, light to a fathomless void. Such an undertaking brings with it a whole host of ethical quandaries when we're talking about narratives of pain: Is it possible to "speak" of trauma? Does the very act of speaking negate the singular nature of trauma? (Alammar, 2021)

Alammar's protagonist is unable to speak of her experiences and the violent transgressions against her body. As Alammar begins to search for Dahlia's voice throughout the narrative, a slow and careful recovery in which Dahlia's healing ultimately means taking ownership of her life, removing it from the collective property of the family and larger society at hand. It is no surprise that the family is unable to let go of Dahlia - she is part of the collective, part of the nation, and they cannot imagine an alternative life for her. What The Pact We Made does is provide an alternative image of Kuwait women. Dahlia's break away from tradition gives birth to her recovery, her ability to choose a path in life. Her ending is an antiBildungsroman ending, where the protagonist chooses not to conform to a traditional ending. Her successful and happy ending lies in her ability to make her first choice, even if it means escaping the family and her homeland, an event that undoubtedly leaves her family with feelings of loss and shame. Alammar ends her final chapter and the last page of the narrative with Dahlia's final thoughts: "I am thirty, and I have made my first decision. I have chosen this; I have chosen him. I have chosen" (Alammar, 2019:274). The word chosen is repeated in complete disbelief. Dahlia has never made an individual choice before; this is her first act of rebellion. 
Yet Dahlia's rebellion is not a loud one - it is quieter, just like she had remained mainly silent throughout the narrative. She packs her bags and leaves, embarking on a new journey of self-discovery and growth. At thirty, an age which to the Western reader implies she has had sufficient experience in adulthood and individual decisions, she is now making her first decision. The Pact We Made grants its protagonist and readers a chance to start over, to break free from stereotypical images of Arab women in literature. Dahlia's narrative is one about freedom from familial restraints, cultural stereotypes and stigmatizing of women, and hope for recovery from trauma. She leaves the mother-nation at her own will. She is not exiled, but rather she reclaims her body and her identity.

\section{Conclusion}

This paper explored the rise of Kuwaiti fiction in English and women's narratives of multifaceted characters negotiating trauma, voice, and agency. Kuwaiti fiction in English is producing more nuanced and alternative images of Kuwaiti women, writing against the dominant patriarchal discourse, and employing protagonists who cannot fit into a stereotypical image. The texts The Hidden Light of Objects and The Pact We Made utilize language and narrative in a nuanced and careful way to avoid perpetuating the same stereotypical images of Kuwaiti women. The protagonists are presented as trying to find their way to the center from the margins, from being silenced and invisible to a more centered narration of their subjectivity. Each of the authors constructs a narrative of voicelessness and a subsequent journey towards self-expression and agency. Like their protagonists, these Kuwaiti women writers are faced with the dilemma of being rendered invisible. In selecting these literary texts, my main concern was critically addressing these narratives by Kuwaiti women writers and calling for their integration into the dominant literary culture due to their significant thematic explorations of trauma, voice, and agency. More scholarly work is needed to address the themes, content and linguistic choices that Kuwaiti women writers must contend with. They are writers that should not be rendered invisible or face the phantom of the maw'udah.

Shahd Alshammari

Gulf University for Science and Technology, Kuwait

ORCID Number: 0000-0002-2364-3231

Email: shahdalshammari@gmail.com 


\section{References}

Abdo, Diya M. (2009). 'How to be a successful double agent): (Dis) placement as strategy in Fadia Faqir's Pillars of Salt.' In Arab Voices in Diaspora, Layla el Maleh (Ed.), 237-69. Leiden: Brill. doi: 10.1163/9789042027190 010

Abdo, Diya M. (2019). 'Notes on the flesh,' Middle Eastern Literatures 22 (1): 58-9. doi: 10.1080/1475262X.2019.1697505

Abu-Khaled, Fawzia. (2014). 'The creative Arab woman: Opposing the stereotypical image and dismantling the prevalent discourse.' In Arab Feminisms: Gender and Equality in the Middle East, Jean Said Makdisi, Nuhá Bayyūmī, Rafĩf Riḍā Șaydāwī, and Ellen Khoury (Eds.), 108-20. London: Bloomsbury.

Alammar, Layla. (2021). 'On the language of revolution ten years after the Arab Spring.' Literary Hub, March 16. https://lithub.com/on-the-language-ofrevolution-ten-years-after-the-arab-spring/

Alammar, Layla. (2019). The pact we made. London: HarperCollins Publishers.

Alenaizi, Hussein, Mohammed. (2018). 'Doing participatory research with disabled people in Kuwait.' Disability Studies Quarterly 38 (2). doi: $\underline{10.18061 / \text { dsq.v38i } 2.5903}$

Al-Mazeedi, Hind, and Alsuwaidan, T. Mohamed. (2014). 'Integrating Kuwait's mental health system to end stigma: A call to action.' Journal of Mental Health 23 (1): 1-3. doi: 10.3109/09638237.2013.775407

Al-Nakib, Mai. (2016). 'Arab literature: Politics and nothing but?' World Literature Today 90, January. https://www.worldliteraturetoday.org/2016/january/arabliterature-politics-and-nothing-mai-al-nakib

Al-Nakib, Mai. (2014). The hidden light of objects. Doha: Bloomsbury Qatar Foundation.

Al-Samman, Hanadi. (2015). Anxiety of erasure: Trauma, authorship, and the diaspora in Arab women's writings. New York: Syracuse University Press.

Alshammari, Shahd. (2017). Notes on the flesh. Malta: Faraxa Publishing.

Al-Yagout, Nejoud. (2019). When the Haboob sings. Self-Published.

Barthes, Roland, and Richard, Howard. (1978). A lover's discourse: fragments. New York: Farrar, Straus and Giroux. 
Bernard, Isabelle and Wael, Rabadi. (2020). 'Contemporary Kuwaiti literature translated into French: The case of Taleb Alrefai.' Canadian Review of Comparative Literature 47 (2): 178-195. doi: 10.1353/crc.2020.0012

Faris, Nada. (2013). Before young adult fiction. Self-published. Does this mean there's no publisher?

Faris, Nada. (2017). Mischief diary. Place of publication? Doha, Qatar: Hamad Bin Khalifa University Press.

Hassan, S. Wail. (2017). The Oxford handbook of Arab novelistic traditions. New York: Oxford University Press.

Kellman, G. Steven. (2013). 'Promiscuous tongues: Erotics of translingualism and translation.' Neohelicon 40: 35-45. _doi: 10.1007/s11059-013-0170-4.

Kellman, G. Steven. (2000). The translingual imagination'. Lincoln: University of Nebraska Press.

Kuwaiti Writers' Association Website. Alrabeta. www.alrabeta.com

Kristeva, Julia, and Alison, Rice. (2002). 'Forgiveness: An interview.' Publications of the Modern Language Association of America 117 (2): 278-95. doi: 10.1632/003081202X62006

Kristeva, Julia. (1984). Revolution in poetic language. New York: Columbia University Press.

Mahmoud, Alaaeldin. (2018). 'Of majors and minors: Reflections on Kuwaiti literature in English.'Anuariou de Literatura Comparada 8: 107-20.

Showalter, Elaine. (1999). A literature of their Own: British women novelists from Brontë to Lessing. Princeton, NJ: Princeton University Press.

Tijani, Olatunbosun, Ishaq. (2008). 'Gendering the Iraq-Kuwait conflict: Literary representations of Kuwaiti women's resilience and resistance.' Journal of Arabic Literature 39 (2): 250-269. doi: 10.1163/157006408X330472.

Tijani, Olatunbosun, Ishaq. (2016). 'Irony and humor as feminist narrative strategies: Arabian Gulf women's literature in perspective.' International Journal of Literary Humanities 14 (2): 9-19, doi: 10.18848/23277912/cgp/v14i02/9-19.

Tijani, Olatunbosun, Ishaq. (2017). 'Kuwait.' In The Oxford handbook of Arab novelistic traditions, Wail, S. Hassan (Ed.). New York: Oxford University.

Tijani, Olatunbosun, Ishaq. (2019). 'Raising feminist consciousness through literature: Two women's texts from the Arabian Gulf.' Journal of Arabian Studies 9 (2): 145-163. doi: 10.1080/21534764.2019.1738034. 
Tijani, Olatunbosun, Ishaq. (2020). 'Feminism and postmodernism in Kuwaiti women's fiction: Four novels by Fawziyya S. Al-Salim.' Open Cultural Studies 2 (1): 61-72. doi: 10.1515/culture-2018-0007. 